\title{
Una memoria ilustrada: problemas de la narrativa gráfica histórica contemporánea en Chile
}

\author{
An Illustrated Memory: Problems of Contempo- \\ rary Historical Graphic Narrative in Chile
}

\author{
Hugo Alexis Hinojosa Lobos
}

Pontificia Universidad Católica de Chile

Candidato a doctor en Literatura (Pontificia Universidad Católica de Chile). Magister en Didáctica de la Literatura y de la Lengua (Universidad Metropolitana de Ciencias de la Educación). Licenciado en Lengua y Literatura hispánica (Universidad de Chile). Licenciado en Educación y profesor en Lengua castellana y Educación (Universidad Andrés Bello). Diplomado en Teoría, edición y creación de literatura infantil y juvenil (IDEA, Universidad de Santiago). Miembro del comité editorial de Dibujos que hablan. Integrante del comité editorial de Revista Había una vez. Académico de la Escuela de Pedagogía en Educación básica, Universidad Academia de Humanismo Cristiano.

Fecha de recepción: 18 de marzo de 2018

Fecha de aceptación definitiva: 30 de noviembre de 2018 


\title{
Resumen
}

La imagen como forma de denuncia y relectura histórica se han vuelto prácticas discursivas comunes al interior de la nueva narrativa gráfica en Chile, en donde las autoras y autores contemporáneos han decidido utilizar el cómic como una plataforma capaz de hablar sobre nuestra propia historia. En cada uno de estos relatos, los elementos visuales propios de la novela gráfica se encuentran al servicio de una tentativa de reconstrucción de la memoria histórica del país, y que desde su ficcionalidad se acercarán a una lectura de nuestro devenir como nación, la cual debe ser problematizada.

Palabras clave: Cómic chileno, dictadura, discurso historiográfico, memoria, novela gráfica

\begin{abstract}
The image as a form of criticism and historical rereading have become common discursive practices within the new graphic narrative in Chile, where contemporary authors have decided to use comics as a platform capable of talking about our own history. In each of these stories, the visual elements of the graphic novel are at the service of an attempt to reconstruct the historical memory of the country, and from their fictionality they will approach a reading of our becoming as a nation, which should be problematized.
\end{abstract}

Keywords: Chilean Comic, Dictatorship, Graphic Novel, Historiographical Discourse, Memory

\section{Cita bibliográfica}

Hinojosa Lobos, H. A. «Una memoria ilustrada: problemas de la narrativa gráfica histórica contemporánea en Chile», en CuCo, Cuadernos de cómic, n. o 11 (2018), pp. 52-80. 
Toda historia es historia contemporánea, en cuanto cada generación la reescribe a la luz de sus propias inquietudes y la utiliza para justificarlas.

Peter Winn

Todo acercamiento a la historia implica una inquietud constante sobre las formas en que nos aproximamos a los hechos, en particular, aquellos que ayudan a configurar una cierta identidad nacional. Si pensamos en la propia trayectoria reciente chilena de los últimos cuarenta años (cruzada inevitablemente por el violento golpe de estado producido en 1973), veremos que nos encontramos en una suerte de encrucijada frente a los discursos propuestos por la historiografía oficial y los de la memoria individual y colectiva que se van cruzando, imbricando y rechazando. Pero ¿qué hay de la historia previa, aquella que no ha sido considerada? ¿Quién hablará en esos discursos olvidados y silenciados?

Por su parte, el cómic en Chile ha logrado un cierto grado de exposición y reconocimiento durante los últimos años (debido a factores de diverso tipo, como políticos, culturales, económicos, etcétera), que lo ha impulsado a un crecimiento exponencial, y que ha permitido que un grupo (todavía minoritario) de investigadores pongan sus ojos en este, los cuales han profundizado tanto en el desarrollo, como en los temas tratados, a través de la publicación de estudios, monografías y catálogos sobre la historieta de nuestro país. Ante una supuesta revitalización del medio historietístico a nivel mundial, potenciada por el aparataje mediático y de mercado de las superproducciones superheroicas del cine, ${ }^{1}$ Chile parece no quedarse atrás, y el medio local goza de un, en apariencia, inmejorable estado de salud. Medios de relevancia a nivel nacional como El Mercurio, a través de su portal EMOL, titulan «Los motivos tras el reciente boom de novelas gráficas centradas en la historia de Chile», ${ }^{2}$ en donde autores como Rodrigo Elgueta, ilustrador de la novela gráfica Los años de Allende, señalan: "[1]os ilustradores chilenos estamos metiendo las manos en la tierra y sacando todos esos temas históricos que nunca antes nos habíamos atrevido a enfrentar». Asimismo, Jorge Rojas, historiador e investigador chileno, indica en el mismo artículo: «[e]1 cómic histórico

${ }^{1}$ Podríamos asumir con libertad que toda esta relevancia del cómic está más bien centrada en sus personajes e historias, por lo tanto, el medio es finalmente desplazado a uno de tipo audiovisual, en donde ya poco importan los códigos de origen, y sí las posibles ganancias derivadas del usufructo de las franquicias desarrolladas a partir de la fuente primigenia.

2 EFE. «Los motivos tras el reciente boom de novelas gráficas centradas en la historia de Chile», en Emol, 18 de junio de 2015. Disponible en http://www.emol.com/noticias/Cultura-y-Espectaculos/2015/06/18/722102/ Pinochet-y-Allende-en-los-comics.html 
puede ayudar a mirar el pasado no como una reliquia o algo anquilosado, sino como un tiempo más fresco vinculado a los problemas actuales. Este tipo de historietas no hablan en abstracto sino que incorporan elementos de contexto a una narración que puede ser leída y observada a través de imágenes».

Pero más allá de las declaraciones alentadoras afirmando el rol de importancia del cómic, ¿hasta qué punto este concepto de boom puede ser abrazado como una realidad? ¿En qué medida este mismo concepto puede resultar engañoso y hasta peligroso? Y, así, podemos constatar la presencia de una creciente explosión editorial que acapara algunas miradas, pero que en verdad no ha logrado calar realmente en la opinión pública. Dicho impacto en un nivel más transversal aún no se ha hecho patente, y, así, el cómic en Chile sigue siendo un espacio de nicho, en donde a ferias y convenciones siguen asistiendo los mismos autores y autoras en un ejercicio de apoyo mutuo, más cercano a la autogestión y el emprendimiento colectivo que a la constitución de una industria madura y consolidada, luego de décadas de trabajo. Un espacio donde todavía siguen siendo limitadas las investigaciones académicas vinculadas al estudio y crítica de las obras, y que queda reducido a algunos pocos sitios y eventos especializados.

En este sentido, me gustaría destacar los trabajos realizados por algunos investigadores nacionales, quienes con estudios realizados en los últimos años, han intentado establecer una mirada histórica y crítica de la historieta del país. Así, tenemos el caso de Udo Jacobsen, investigador y docente de la Escuela de cine de la Universidad de Valparaíso, quien, en 2001, edita Leyendo Cómics. Una guía introductoria al lenguaje de la historieta, una de las pocas obras publicadas en Chile que se aboca al análisis del cómic como lenguaje. Por su parte, Cristián Díaz, dibujante, guionista y coleccionista chileno, autor del Capitán Chile, realiza la investigación La historieta en Chile, publicada el año 2002 en la Revista latinoamericana de estudios sobre la bistorieta, donde recoge la trayectoria extensa del cómic en el país. Luego tenemos el trabajo de Jorge Montealegre, poeta, periodista y académico de larga trayectoria, quien ha publicado una serie de trabajos en donde se rescata parte de la historia del cómic nacional. Entre ellos se destacan Prehistorieta de Chile, del arte rupestre al primer periódico de caricaturas (2003); Historia del Humor Gráfico en Chile (2008); Nato, la sonrisa imborrable (2012), junto a Claudia Andrade; Rodrigo Lira, un poeta en la tierra del cómic (2014); Von Pilsener, primer personaje de la historieta chilena (publicado en 1993 y reeditado durante el 2016), entre otros. Por otra parte, tenemos la detallada investigación del ya nombrado Jorge Rojas Flores, académico de la Pontificia Universidad Católica de Chile, quien en 2016 edita Las historietas en Chile. 1962-1982 Industria, ideología y prácticas sociales, uno de los libros más documentados sobre un periodo específico de la historia del cómic nacional. También está el trabajo de Moises Hasson, coleccionista e investigador independiente, quien, a través de su propia editorial, ha publicado una serie de obras de consulta y catálogo, de gran relevancia para la investigación sobre cómic en Chile. Estas son: Comics en Chile. Catálogo de Revistas. 1908-2000 (2014), Pin-Up. Comics Picarescos en Chile (2015) y Sátira Politica en Chile (2017), al que se suma Viaje de la Tierra a Marte (2017), rescate de la primera historieta de ciencia ficción publicada en Chile en 1924. Finalmente, tenemos el trabajo de investigadores jóvenes como Paloma Domínguez, Mariana Muñoz, 
Jorge Sánchez o Alejandro Ocaña, quienes con sus trabajos están entrando lentamente a los espacios académicos institucionalizados.

\section{Un breve panorama sobre el cómic y su relación con la historia en Chile}

Para situar la discusión, es relevante trazar un cierto derrotero por el que ha venido transitando el cómic chileno durante los últimos años, y ha permitido instalar las condiciones del proceso de supuesto desarrollo que se ha dado en la narrativa gráfica en nuestro país durante los últimos años. Chile es heredero de una larga tradición de cómic, reconocible en obras icónicas como Mampato, Condorito, Barrabases, entre otras, pero que luego de la llamada «edad de oro» (durante los años sesenta y setenta, primero, bajo la explosión editorial de la mano de Zig-zag, y luego en la editorial estatal Quimantú) vivió un proceso abrumador de estancamiento, en el cual la manufactura nacional se vio minimizada y relegada al mundo del underground durante la década de los ochenta, producto del brutal periodo de dictadura militar. Despreciado por gran parte del mundo académico, o catalogado como producción ficcional de segundo orden, el cómic recién ha logrado un auge en Chile durante los últimos casi siete años, y en donde ha podido obtener un crecimiento exponencial, tanto en cantidad como en calidad, pero que no implica, bajo ninguna circunstancia, un regreso a los tiempos de esplendor pasados, sino más bien responde a nuevos modelos de producción.

En ese sentido, la experiencia de autogestión y supervivencia dada durante la dictadura supuso, al parecer, una novedosa forma de abrirse paso ante las condiciones adversas. Experimentación, tanto temática como formal, modos alternativos de producción, publicación y difusión marcaron la pauta de los primeros años durante los noventa y la década del dos mil, y que recién surte un efecto de recuperación de la escena. Frente a la amplia oferta editorial actual, en cuanto a temáticas, géneros y rangos etarios, no debería entonces extrañarnos un fenómeno particular, que en una mirada preliminar llama la atención. Los autores y autoras han decidido comenzar a utilizar la plataforma narrativa visual como soporte de una escritura que permita mirarnos a nosotros mismos, desde nuestra propia historia e identidad, entendiendo al medio narrativo visual, como una manera particular de articular un relato histórico desde la ficción, y canalizando en parte el ejercicio político manifestado en obras como las del filósofo Georges Didi-Huberman.

Es aquí donde se plantea un primer atisbo de análisis a considerar. Aquellas voces desplazadas por la historia, asumen una condición de silenciamiento, de negación de la palabra y el discurso. Desde esa perspectiva, la emergencia de una narrativa gráfica centrada en ciertos hechos históricos, viene a ser el vehículo que permite que se releven ciertos discursos anclados en la memoria. La imagen articulada como el soporte de expresión de un silencio impuesto históricamente.

Por otra parte, este mismo trabajo de indagación realizado por investigadores como Rojas, Hasson, Montealegre, y otros es el que revela que la tradición del cómic vinculado a la relectura de la historia no es nueva, ni mucho menos. Desde las ficcionalizaciones de la his- 
toria de Chile en las aventuras de Mampato, en relatos como «La reconquista» o «El cruce de los Andes», a la adaptación ilustrada de la célebre Adiós al séptimo de línea, novela sobre la Guerra del Pacífico escrita por Jorge Inostroza. Desde el paso de la revista de aventuras Intocable a El guerrillero, historieta centrada en la figura icónica de Manuel Rodríguez, héroe del proceso de independencia chileno, editada en el período de la recordada Quimantú, o el trabajo de Historia de Chile en cómic publicado por el diario Las últimas noticias en el año 2008, son solo algunos de los tantos ejemplos que considerar como antecedentes para el fenómeno de producción actual. Y a pesar de este pasado, pareciera que es justo ahora que los autores y autoras locales han decidido osar a contar aquellos episodios que antes no se habían atrevido a narrar, hechos dolorosos o desconocidos, que encuentran en el lenguaje del cómic un soporte escritural apto para mostrar dichos episodios. Pero podríamos comenzar a tensionar dichos relatos, al considerar que estos se construyen a partir de fuertes trabajos de investigación, en fuentes historiográficas y literarias que ya registran esos episodios que al parecer antes no fueron tomados en cuenta. Entonces la discusión no debería centrarse desde el plano de una supuesta «historia oficial» (si es que existiera una historia de ese tipo) versus otra que ha sido ocultada, sino preguntarnos de qué forma estos nuevos relatos gráficos recogen estos episodios, antes dejados de lado.

$\mathrm{Y}$ es evidente que en el ejercicio de reconstruir o narrar la historia desde la visualidad a través del cómic, hay una necesidad de legitimación de ciertos grupos que se han visto desplazados de la opinión histórica tradicional, pero tras esta acción se esconde una pregunta tanto o más relevante: ¿Qué es lo que se da a ver? ¿Qué se nos quiere mostrar? Ahora, la pregunta previa y central que deberíamos realizar es: ¿por qué este medio para narrar la historia nacional? Cómo señala el historiador Roger Chartier «Las percepciones sociales no son de ninguna manera discursos neutrales: producen estrategias y prácticas (social, política educativa,) que tienden a imponer una autoridad a costa de otros, por ellos menospreciados, legitimar un proyecto de reforma o justificar, para los propios individuos, sus decisiones y comportamientos». ${ }^{3}$ Así, tal y como apunta Didi- Huberman, ${ }^{4}$ en el proceso de la representación se propone que, al exponer, a la vez se está haciendo un reparto. Este reparto no asume a la comunidad como la diversidad de voces e imágenes, en el cual las singularidades conforman el todo, sino más bien el contrario, es el nosotros que se escinde, que se reparte y se hace evidente en la exposición. Esta exposición implica una dialéctica, en donde se conjugan una comunidad que se expone (puesta en reparto) y una comunidad expuesta a (puesta en peligro), espectáculo-escudo social, son las alternancias que deben ser consideradas al interior de un pensamiento que se asume a si mismo como político.

En la exposición de los pueblos (y sus historias), la intención de buscar el punto de comunidad, la construcción del lugar en común es opacada por un lugar común, una fórmula preconcebida. Es la representación de dicha comunidad donde se corre el riesgo de la edificación

${ }^{3}$ Chartier, R. A História Cultural: entre práticas e representaóes. Río de Janeiro, Editora Bertrand, 1990, p. 17.

${ }^{4}$ Didi - Huberman, G. «Repartos de comunidades», en Pueblos expuestos, pueblos figurantes. Buenos Aires, Manantial, 2014, pp. 95-146. 
de un estereotipo, una forma que se torne limitada en la contingencia. Por el contrario, las imágenes deberían efectivamente constituir y generar una noción de comunidad, la cual se encuentra implícita en la misma etimología de la palabra, es decir, la imagen constituyendo el lugar en común, el espacio del colectivo. En ese sentido, la comunidad, al revelarse (y rebelarse) está mostrando su naturaleza, la cual es ajena a las construcciones que hace de ella el poder. $Y$ es en aquel acto de negación al sometimiento en donde se afirma la potencia de una comunidad. Por lo tanto, la representación de la historia realizada por el cómic es un gesto profundamente político, y que revela la necesidad de la lectura crítica de estos discursos.

\section{El cómic como un discurso para la historia y la memoria}

Del mismo modo en que escritores y escritoras vieron en la literatura una manera de narrar lo que es Chile y sus hechos (como un ejercicio de representación histórica), nuevos guionistas e ilustradores han optado por tomar como materia de sus novelas gráficas la propia historia nacional. Es así que comienza a desarrollarse una nueva lectura histórica, que permite comprender parte de lo que somos desde el espacio de la ficción, ahí en donde el cruce entre lo histórico y lo propiamente visual cobra relevancia.

Pero más allá de una relación del cómic con lo literario, debemos preguntarnos: ¿en qué lugar debemos situar a este, dentro de un contexto de producción intermedial (y transmedial) creciente? La pregunta se vuelve relevante para poder ubicar la historieta en el momento de una transformación esencial de la cultura, en donde la sociedad ha mutado hacia la revolución digital. El siglo XxI se nos revela como un instante en donde la idea de un futuro, tan arraigado en las generaciones pasadas, se ha difuminado y se busca una experiencia única del presente, la ilusión de que todo ocurre al mismo tiempo. De este modo, la mayoría de los fenómenos se van volviendo deliberadamente opacos, y el medio natural es suplantado por uno técnico. Es así que, como señala Silvestra Mariniello en su texto Cambiar la tabla de operación. El medium intermedial, el espacio intermedial «nos aparta del pensamiento de la representación y de la puesta a distancia para introducirnos más bien en el pensamiento de la mediación y de la inmanencia». ${ }^{5}$ El llamado «arte secuencial», como lo señalaba Will Eisner, finalmente ha intentado posicionar su lugar como espacio válido de narración, de mediación, que establece estructuras tan complejas como las que desarrolla un texto literario para generar interpretaciones de la historia nacional.

Ya comprendiendo algunos de los mecanismos que utiliza el cómic para articular su discurso, deberíamos ver como se entronca esto con el proceso de mediación histórico. Es evidente que a través del desarrollo histórico de una nación (cualquiera sea esta), algunos discursos e imágenes son ignorados y silenciados por parte de una élite política, económica o religiosa. Olvidados, e incluso negados por la ciudadanía, estos episodios usualmente circulan como una suerte de «imaginario del margen», que intenta emerger en la discusión pública. Desde

5 Mariniello, S. Cambiar la tabla de operación. El medium intermedial. México, Revista Acta Poetica 30-2, otoño 2009, p.62. 
este modo, retomando lo establecido por autores como Georges Didi Huberman o Jacques Ranciere, quienes considerando que el espacio de la representación es un campo en disputa, es pertinente comprender que el juego de la imagen y la representación en el interior de una novela gráfica debe ser asumido como un gesto político.

Pero ¿qué entenderemos por novela gráfica para este contexto específico de producción ficcional-histórico? ${ }^{6}$ Como señala Manuel Trabado, deberíamos considerar la novela gráfica «como una forma de cómic de autor [...] desalojados los imperativos que parecían hacer seguir las fórmulas del género», 7 aunque no entendida desde una lógica intimista o limitada a lo autobiográfico. A su vez, también puede ser comprendida como un «formato enriquecido» ${ }^{8}$ que podría surgir de la acumulación o reestructuración de un formato previo que todos pudieramos reconocer, estableciendo un código en común entre los creadores y sus lectores/ as. Esto implica obviamente cambios no solo en aspectos puramente formales o narrativos, sino en la posición que ocupa su lector.

Esta condición específica que fomenta la novela gráfica permite potenciar la idea de que la imaginación social no es reductible a una función especular, en la cual las imágenes funcionan como identificaciones o alienaciones, sino más bien se erige como un lugar de la experimentación y la posibilidad. Debido a este proceso de reflexión sobre la imagen, es que la política se ha vinculado a la estética, en cuanto la primera se involucra a la noción de reparto, y a su vez a la de exposición cultural. Esto nos deriva inexorablemente a un problema de la representación, del conflicto político implícito en ella. Al hablar de «discursos silenciados» se establece una doble significación. Por una parte, refiere a ciertos temas u obras que han silenciados producto de su propio discurso, pero también hace referencia al cómic producido en Latinoamérica, y en este caso en particular en Chile, el cual ha sido invisibilizado ante la producción europea o norteamericana de historieta.

Para ello hay una selección particular de imágenes, las cuales derivan de ciertas construcciones ideológicas y que pueden dar pie, por ejemplo, a la generación de estereotipos. Este aspecto es muy importante, porque en ella hay una decisión que no es solo estética, sino también política. Es por esto que muchas veces debemos recurrir a la propia voz de los participantes de los hechos acontecidos. No olvidemos que, como señala Gaborit, citando a Middleton y Edwards, la memoria «es sobre todo un acto social más que un contenido mental individual». ${ }^{9}$ Este particular proceso subraya el valor de la narrativa (en este caso

${ }^{6}$ Aún cuando hablamos de historieta y cómic como homólogos, se vuelve problemático al entrar la categoría de novela gráfica. Al respecto, es importante precisar que entenderemos a esta última como un formato más dentro de la historieta (al igual que la tira cómica, el comic book, etc.) En ese sentido, afirmo que toda novela gráfica es cómic, pero no todo cómic es novela gráfica.

7 Trabado, J. M. «La novela gráfica en el laberinto de los formatos del cómic», en La novela gráfica. Poéticas y modelos narrativos. Madrid, Editorial Arco/Libros, 2013, p.11-61

8 Ibid. P.34

9 Gaborit, M. «Memoria histórica: relato desde las víctimas», en Pensamiento Psicológico, vol. 2, n. 6 (2006), pp. 7-20. 
gráfica) al mediar la realidad, donde en esta construcción se intenta dotar de un sentido al pasado, por lo tanto, exige la emergencia de nuevos relatos factuales y ficcionales, en donde se entrecruzan el tramado histórico y la disputa por una cierta verdad histórica, considerando que no existe una mirada unívoca. En ese sentido, siguiendo lo planteado por Hayden White sobre Maus, este se asume como un texto críticamente autoconsciente al narrar los hechos de la segunda guerra mundial y el holocausto judío, pero sin pretender cerrarlos o afirmarlos como la verdad absoluta. Según Trabado, en esa perspectiva: «Spiegelman lo hace acudiendo a otra coordenada esencial: la del tiempo y su recuperación en forma de memoria; se trata de otro modelo compositivo de novela gráfica: una novela gráfica de la memoria». ${ }^{10}$

Desde esta perspectiva, el cómic, en su estatus de medio de la visualidad y la secuencia, $\mathrm{y}$ asumiendo su rol como marginalidad cultural, se ha involucrado desde su lenguaje a aquellos discursos históricos que también han sido excluidos. Considerar la imagen como forma de denuncia y relectura histórica se ha vuelto una práctica discursiva común al interior de la nueva narrativa gráfica en Chile. Considerando su propia historia de resistencia como medio (que puede hallar su génesis en el cómic underground producido en la década del ochenta, durante la época de dictadura), las y los autores contemporáneos han decidido utilizar el cómic como una plataforma capaz de hablar sobre nuestra propia historia social.

Pero no es solo la cuestión acerca de la representación, sino también sobre la memoria, y cómo, en estos textos en particular, opera un dispositivo de recuperación de una identidad colectiva, una historia que se siente propia, pero que ha sido silenciada por la historia oficial. En cierto modo, los autores y autoras de estas obras, operan como portavoces de un discurso con una fuerte matriz ideológica, y que en la mayoría de los casos surge de una necesidad de reescribir o re-imaginar (entendido como el proceso de construcción de nuevas imágenes) ciertos hechos conflictivos o traumáticos dentro de la historia de Chile. Ahora, el choque entre un discurso desde la historia y otro articulado desde la memoria será relevante en la forma en que los propios cómics nacionales articulan sus narraciones. Al respecto, Peter Winn explica:

Historizar la memoria significa someterla a un análisis histórico crítico, y hasta deconstruirla. Y los resultados de ese análisis pueden poner en entredicho la memoria colectiva estudiada, mostrarla como una construcción social o política y no como la verdad sin tacha que sus partidarios atesoran como un artículo de fe. ${ }^{11}$

Pero, en definitiva, ¿qué es representar? Y, más aún: ¿qué implicaría representar la historia?

10 Trabado, J. M., Op. cit., p. 20.

${ }_{11}$ Winn, P. «El pasado está presente. Historia y memoria en el Chile contemporáneo», en Historizar el pasado vivo. Universidad Alberto Hurtado, 2007, p. 28. Disponible en http://www.historizarelpasadovivo.cl/ downloads/winn.pdf 
Stuart Hall señala que «es una parte esencial del proceso mediante el cual se produce el sentido y se intercambia entre los miembros de una cultura. Pero implica el uso del lenguaje, de los signos y las imágenes que están por, o representan cosas». ${ }^{12}$

Frente a esta definición la pregunta sería: si el cómic opera bajo un lenguaje con condiciones particulares establecidas (mayormente visuales), ¿de qué modo este lenguaje produce sentido en su ejercicio de representación?

\section{Cómic y mediación histórica}

Volvamos atrás. La literatura se ha hecho cargo de contar la historia en múltiples oportunidades, bajo el beneplácito (o no) de la Historia, esa con mayúsculas. Esta problemática de la narración literaria frente al relato histórico no es una discusión menor, dado que establece límites difusos entre los discursos de carácter ficcional, y los que no lo son. Desde dicho punto de vista, en esencia toda historia es siempre un relato y, como relato, se torna una construcción, una ficción que terminará, sin duda, formando y deformando las realidades, y, dado que la novela gráfica chilena actual hace una interpretación de la historia, es innegable que los problemas que se han suscitado entre la literatura y su relación con el discurso historiográfico son relevantes también para esta discusión.

Para Hayden White, ${ }^{13}$ los modos de representación de la historia durante el siglo xix (y que a su vez adoptó la literatura), se vieron limitados en el siglo xx por la aparición de lo que él denominó «eventos modernistas», sucesos complejos y violentos que cuestan ser asimilados, y no tienen un sentido único debido a su carácter traumático. Estos eventos no logran unanimidad en su significado, porque su representación ya no es posible desde los cánones clásicamente establecidos. Es así que la literatura modernista del siglo xx desarrollada por autores como Joyce, Faulkner o Woolf se abre a nuevos modos de representación, en donde los textos se abren. Este espacio es el que también transita la narrativa gráfica para poder acercarse a dichos eventos. Al respecto, White señala el ejemplo relevante de Maus, que se sitúa como modelo de obra que logra acercarse al relato de los terribles hechos de la segunda guerra mundial. Ante este ejercicio de representar lo irrepresentable, Andreas Huyssen afirmará que «[1]a tesis del carácter único del Holocausto en la Historia se refleja estéticamente en la búsqueda de un único modo lícito y adecuado de representar el genocidio.» ${ }^{14}$

Pensando en el caso planteado por Maus, ante la pregunta de la representación de los eventos modernistas, pareciera que la cuestión no está en la validez o no de un relato que lo

12 Hall, S. «El trabajo de la representación», en Representation: Cultural Representations and Signifying Practices. London, Sage Publications, 1997, pp. 13-74. Traducido por Elías Sevilla Casas.

13 White, H. El contenido de la forma. Narrativa, discurso y representación histórica. Barcelona, Paidós, 1992; y El tex to histórico como artefacto literario. Barcelona, Paidós, 2003.

${ }^{14}$ Huyssen, A. «El Holocausto como historieta. Una lectura de Maus de Spiegelman» En En busca del futuro perdido cultura, memoria en tiempos de globalización. Mëxico, FCE, 2001, pp. 119-141. 
aborde, sino más bien en su forma, el cómo poder narrar lo inefable. Ahora, este problema en torno a la forma, impacta directamente a un medio condicionado históricamente por sus vinculaciones con la cultura popular. Tal como afirma Huyssen: «el debate sobre la correcta representación fílmica del Holocausto solo reproduce el antiquísimo debate sobre alta modernidad versus cultura de masas, a su vez fuertemente ligado con una relación de mutua especularidad entre Norteamérica y Europa». ${ }^{15}$ Es así que este conflicto se vuelve relevante, en la medida que el cómic ha sido asociado a los medios másivos de comunicación, sin ahondar en las dimensiones artísticas y estéticas que ha logrado desarrollar. De ahí que se comprenda el constante y majadero discurso de validación en torno a su lenguaje, sus autores y obras. Ahora, esta relación inicial se complejiza al considerar al cómic desde su contexto latinoamericano (y chileno), por tanto, habría que hacer un rastreo de las claves culturales que lo sustentan. Ante esta disyuntiva, Nestor García Canclini se pregunta: «Cómo analizar las manifestaciones que no caben en lo culto o lo popular, que brotan de sus cruces o en sus márgenes?» ${ }^{16}$

Desde otra arista, tal como señala Wlad Godzich (citado por Mariniello), los problemas contemporáneos de la representación se producen cuando:

Modern consciousness knows itself to be a consciousness of falsehood and accepts this fact; it knows that this means that it cannot generate a narrative capable of totalizing the meaning of existence and of the world. This ultimate step in the demystification of the world, accelerated by some historical catastrophes. ${ }^{17}$

En una sociedad que avanza vertiginosamente, la necesidad de reencontrarse con la propia memoria histórica, empuja a los individuos a intentar reconstituir de alguna forma los procesos sociales, políticos, culturales, e incluso personales que llevaron a los eventos traumáticos de su propia historia. Como afirma Huyssen «en la era de los medios, es ante el tema del "Holocausto" donde se articula de la manera más clara el terror a la pérdida de la realidad en la representación». ${ }^{18}$ Pero más que pensar en una representación que pueda ser más menos fidedigna de los hechos históricos, deberíamos pensar desde la lógica intermedial, comprendiendo que efectivamente debe haber una mediación entre la experiencia real o imaginaria que constituye el acontecimiento, y la experiencia de los lectores, que permita releer desde una nueva perspectiva lo acontecido. Del mismo modo, señala: «precisamente porque Auschwitz se sustrae a toda representación unívoca que busque establecer un sentido, el acontecimiento "Auschwitz" sigue necesitando de una multiplicidad de representacio-

15 Huyssen, A. Op. cit., p. 125.

${ }^{16}$ García Canclini, N. Culturas hibridas. Estrategias para entrar y salir de la modernidad. México, Editorial Grijalbo, 1990, p. 263.

17 «La conciencia moderna sabe que es una conciencia de falsedad y acepta este hecho; sabe que esto significa que no puede generar una narrativa capaz de totalizar el significado de la existencia y del mundo. Este último paso en la desmitificación del mundo, acelerado por algunas catástrofes históricas» [traducción propia]. En Mariniello, S. Op. cit., p. 70.

${ }_{18}$ Huyssen, A. Op. cit., p. 120. 
nes si de mantener viva su memoria se trata». ${ }^{19} \mathrm{Y}$ en esa lógica, el cómic se manifiesta como un medium privilegiado para esta tarea.

En retrospectiva, el nuevo avatar de los tiempos impactó en el desarrollo del lenguaje del cómic que, para García Canclini, pudo «generar nuevos órdenes y técnicas narrativos, mediante la combinación original de tiempo e imágenes en un relato de cuadros discontinuos, contribuyó a mostrar la potencialidad visual de la escritura y el dramatismo que puede condensarse en imágenes estáticas». ${ }^{20}$ En ese sentido, el concepto de intermedialidad, pensando desde la lógica texto-visual del cómic, «parece poder suministrar señales en el camino de la renovación de la literacy [...] lleva el análisis fuera del campo lingüístico y literario». ${ }^{21} \mathrm{Si}$ el cómic ha podido ir actualizando sus formas y técnicas, podríamos aventurarnos a afirmar que este, en su condición de imagen-texto, es un espacio intermedial por excelencia, comprendiéndolo como «el espacio híbrido donde el discurso se abre a lo visible y la visualidad se convierte en discursiva en un movimiento que perturba la construcción lingüística y filosófica que las tenía separadas». ${ }^{22}$ Pero, sobre todo, considerando que en la constitución de una obra intermedial, que podría corresponder al cómic, el sujeto «no puede ignorar la superficie sobre la que la letra toma forma, ni la base material del medium, las modalidades de transmisión, la materialidad de la comunicación», ${ }^{23}$ en una relación que, como señala Mariniello, es intrínseca entre el material y su medium para poder darle forma a la mediación, al hacer.

Este ejercicio de «puente» producido por la mediación, permite al medio (en este caso texto-visual) vincular el hecho histórico representado con la experiencia del propio espectador-lector. Al igual que en la posibilidad de la técnica audiovisual de develar la vida misma, la técnica en el cómic (por ejemplo, el montaje de las viñetas para producir una secuencia determinada de imágenes) podría develar, en el caso de los cómics históricos, el conocimiento de un proceso específico del devenir de la historia, y que se resiste a ser representado: hace evidente los límites de su representación en aquella distinción ya inexistente entre lo real/imaginario. En ese sentido, concuerdo con Mariniello en concebir la técnica como el acontecimiento, más que como el medio para poder articular un gran relato. De esta forma «la imagen confiere una presencia imaginaria a lo real, el mundo existe en cuanto imagen y la imagen se adhiere a la realidad del mundo que está presente en ella fuera de la oposición real/imaginario». ${ }^{24}$

Si pensamos en el caso de Art Spiegelman, veremos que reconoce abiertamente en una entrevista su deseo de crear un relato inauténtico, es decir, buscar una camino alternativo

\footnotetext{
19 Ibid., p.123.

20 García Canclini, N. Op. cit., p. 316.

${ }^{21}$ Mariniello, S. Op. cit., p. 75.

${ }^{22}$ Ibid., p.78.

${ }^{23}$ Idem.

${ }^{24}$ Ibid., pp. 71-72.
} 
para poder escudriñar en el horror del Holocausto, tantas veces retratado, pero nunca cerrado como gran relato. Bajo esta perspectiva, según Andreas Huyssen, «el reconocimiento de la inexorable inautenticidad deviene condición necesaria para una nueva forma de autentificación». ${ }^{25}$ Es ahí que el medio del cómic, su técnica, permite reconstituir el acontecimiento, mediando entre la experiencia privada y familiar de Spiegelman y la experiencia colectiva y universalizada del Holocausto. Para ello, manifiesta abiertamente su inautenticidad, su carácter de real-imaginario, al recubrir a los sujetos de una condición de animalidad, que mutara de la representación de animales antropomorfizados, hasta el ejercicio del simulacro de la máscara en su autor. Es así que la imagen retratada, construida por el autor, permite reconstituir a través del montaje los diversos tiempos, lo que para Huyssen «articula un pasado que no puede pasar y permite al lector acercarse a esa ligazón traumática con el pasado sin caer en una parálisis mimética». ${ }^{26}$ posibilitando otra forma de acceder al trauma y el horror. Finalmente, para Huyssen, en Maus se «supera con rigor único el conflicto entre la representación objetiva, documental (que finalmente anestesia al lector u observador respecto del sufrimiento individual) y el testimonio subjetivo autobiográfico (que solo genera empatia y conmoción respecto del padecer individual)», ${ }^{27}$ por lo cual la estrategia derivada de la técnica y el lenguaje del cómic, se vuelve efectiva, la que al parecer los autores y autoras chilenos han logrado integrar a sus obras.

\section{Tres miradas a la dictadura}

Al considerar que la producción de novelas gráficas chilenas con temática histórica ha ido en aumento, se vuelve complejo poder analizar cada una de ellas; es por esta razón que he decidido centrarme en tres de estas que han abordado el golpe de estado y la dictadura cívico-militar, tomando a este momento histórico como emblemático para la historia reciente del país. Es así como durante los últimos años se han venido desarrollando ciertos procesos de irrupción de la memoria en donde, a través de la escritura en diversos soportes textuales, se ha intentado buscar una respuesta o una voz a este período especialmente traumático de la historia de Chile. En particular, nos acercaremos específicamente a este desde el análisis de tres novelas gráficas chilenas recientes; a saber, Los años de Allende ${ }^{28}$ de Carlos Reyes y Rodrigo Elgueta, El golpe. El pueblo 1970-197329 de Nicolás Cruz y Quique Palomo, e Historias Clandestinas ${ }^{30}$ de Ariel y Sol Rojas Lizana, las cuales abordarán desde diferentes momentos y perspectivas el suceso.

\footnotetext{
25 Huyssen, A. Op. cit., p. 127.

${ }^{26}$ Ibid., p. 129.

27 Ibid., p. 131.

28 Reyes, C. y Elgueta, R. Los años de Allende. Santiago, Editorial Hueders, 2015.

29 Palomo, Q.y Cruz, N. El golpe. El pueblo 1970-1973. Santiago, Pehuén Editores, 2014.

30 Rojas Lizana, A. y Rojas Lizana, S. Historias clandestinas. Santiago, Lom Ediciones, 2014.
} 


\section{El golpe. El pueblo 1970-1973. El antes y el ahora}

Publicada como primera parte de una obra mayor durante el año 2014, esta novela gráfica escrita por Nicolás Cruz e ilustrada por Quique Palomo (FIG. 1), abordará el proceso de llegada al poder de la UP y, posteriormente, los incidentes que generarán la crisis política-económica que conducirá al golpe de Estado de 1973.

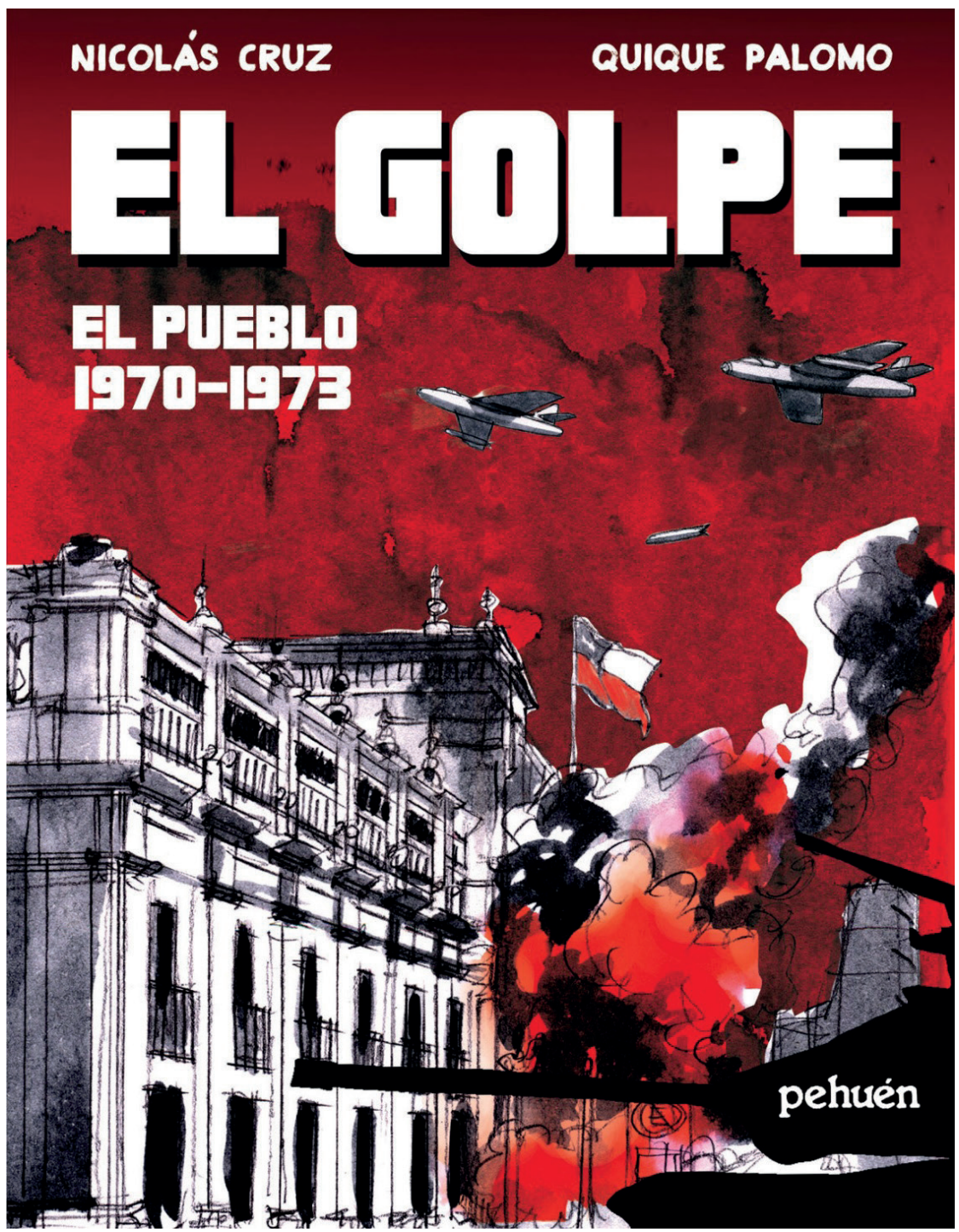

FIG. 1. Palomo, Q.y Cruz, N. El golpe. El pueblo 1970-1973. Santiago, Pehuén Editores, 2014.

Como obra de ficción centrada en el gobierno de la UP y el golpe de estado, es interesante que arranque no desde el pasado, sino desde el presente. Veremos una protesta estudiantil en pleno conflicto «pingüino» del 2011, donde, además, se hará énfasis en el actuar represi- 
vo de las fuerzas policiales y que será destacado tanto por la prensa como por figuras relevantes de aquel momento como Camila Vallejos, presidenta de la FECH durante ese período, actualmente diputada (FIG. 2). Como resultado de las manifestaciones, una joven de nombre Paula Quezada se verá arrestada junto a otros compañeros y compañeras.

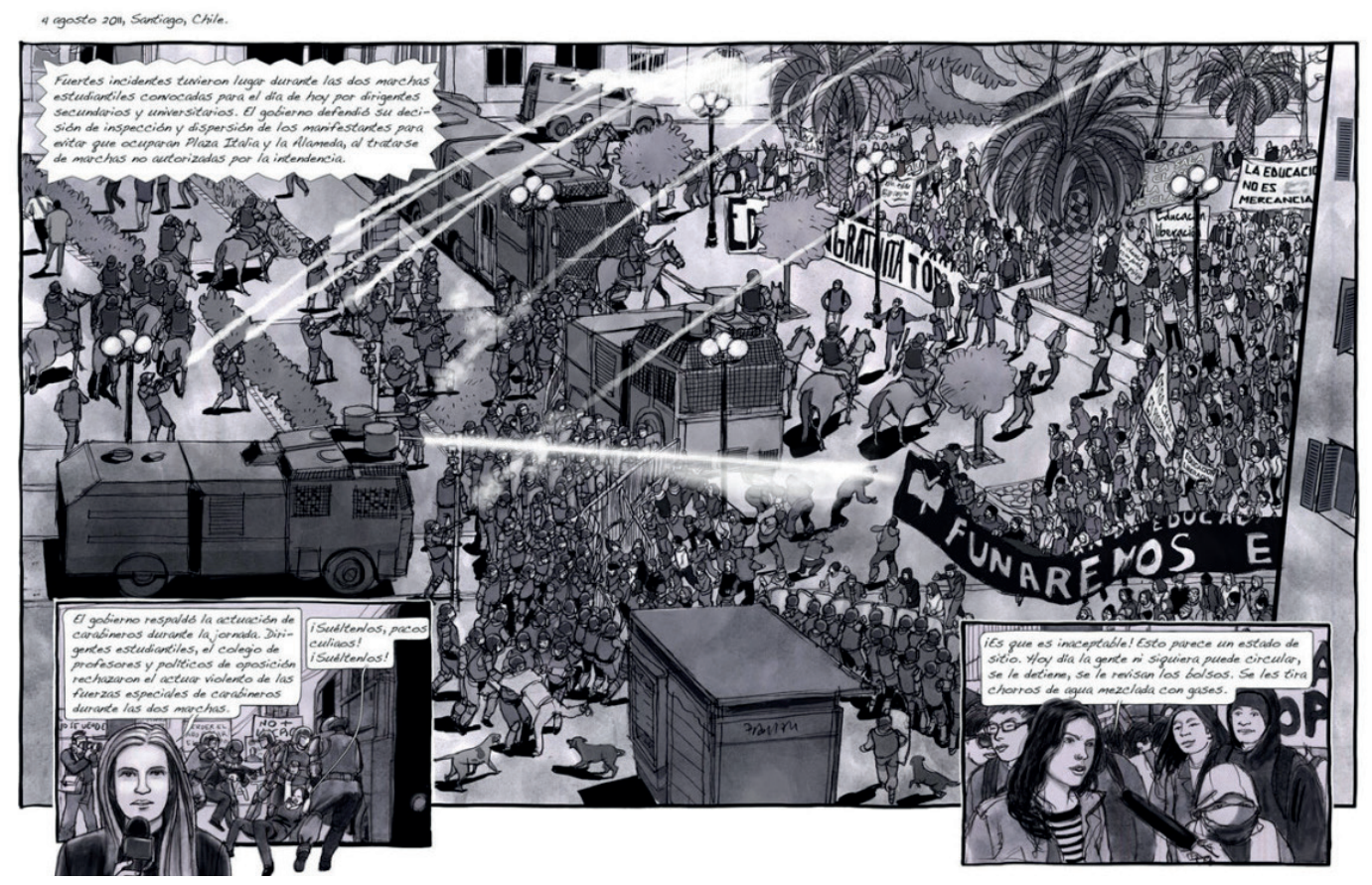

FIG. 2. Palomo, Q.y Cruz, N. El golpe. El pueblo 1970-1973. Santiago, Pehuén Editores, 2014. Las imágenes dan cuenta de la represión policial, como de la presencia de los líderes estudiantiles.

Esta situación en particular llevará a que su padre, afectado por el incidente, comience un proceso de reconstrucción de su memoria, y relacione lo ocurrido con lo sucedido casi cuarenta años atrás. No es de extrañar que este hecho manifieste el trauma presente en muchos ciudadanos y ciudadanas chilenas, quienes en la manifestación y su contención por parte de la policía creen ver los resabios de un pasado oscuro y altamente violento. En ese sentido, la angustia producida por la represión se trasladó al ámbito de lo privado, y cuando este es afectado es el momento en que aflora la memoria para hacer una relectura de lo pasado. Como señala Alexander Wilde:

Los temas de derechos humanos y la memoria histórica del país interesan a toda la nación y no sólo a las familias directamente afectadas o a las organizaciones de izquierda que quedaron luego del movimiento histórico por los derechos humanos. Lo que Chile en su conjunto experimentó durante la dictadura —e incluso durante el tiempo de profundas divisiones nacionales, más prolongado que aquélla y anterior a 1973 - es el tema de esa memoria. ${ }^{31}$

${ }^{31}$ Wilde, A. «Irrupciones de la memoria: la política expresiva en la transición a la democracia en Chile», en Historizar el pasado vivo, Universidad Alberto Hurtado, 2007, p. 35. Disponible en http://www.historizarelpasadovivo.cl/downloads/wilde.pdf 
Es por eso que basta que una hija sea detenida por la policía durante una manifestación para que afloren los recuerdos de aquel periodo. Las conversaciones familiares, los discursos en apoyo y en rechazo al posible gobierno de Allende y, finalmente, la constante polarización social y política marcan la pauta social desde 1970 en adelante.

Por otra parte, las imágenes tienden a escenificar desde sus viñetas los diversos aspectos de la sociedad de la época, añadiendo además algunas imágenes fotográficas que apuntan a construir un aspecto testimonial o documental sobre los hechos acontecidos. Es importante señalar que aun cuando podemos reconocer un esfuerzo por recrear de una manera más o menos fidedigna el período retratado, el discurso que el relato propone a lo largo de su desarrollo tiende a idealizar el proceso de constitución de la Unidad Popular y su posterior gobierno. Para este fin, la figura de Allende se verá enaltecida constantemente, destacando sus discursos e intervenciones públicas en donde se hace manifiesto su programa de gobierno, que posteriormente se verá cercenado por los incidentes de septiembre de 1973. (FIG.3)

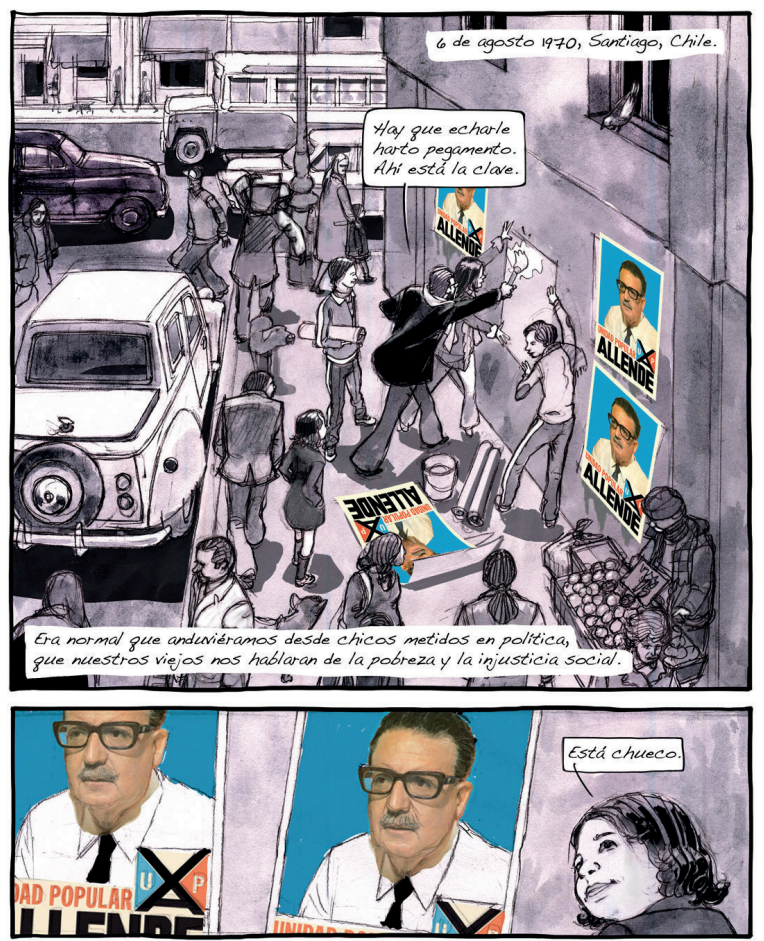

FIG. 3. Palomo, Q.y Cruz, N. Op. cit. Parte de la campaña de la U.P. (Unidad popular) a inicios de los setenta. La obra hace utilización de montajes fotográficos para mostrar parte de la época.

En paralelo con los hechos propiamente históricos, el relato construye una ficción a partir del recuerdo de este padre del presente, y que de joven fue testigo presencial de los diversos acontecimientos que se fueron sucediendo, como el proceso para la elección de Allende (y la gran expectativa social que esta votación generaba en distintos bandos políticos), el atentado contra el general Schneider, o la premiación del Nobel de Neruda, entre otros. Así, también 
sabremos que la madre de este joven del pasado era socialista y trabajaba en el servicio de salud pública, y que el padre era adherente de Allende. Asimismo veremos como parte de la población (principalmente jóvenes), producto del ideario que proponía la Unidad Popular, se abocará a acciones sociales, como la educación en sectores desposeídos económicamente.
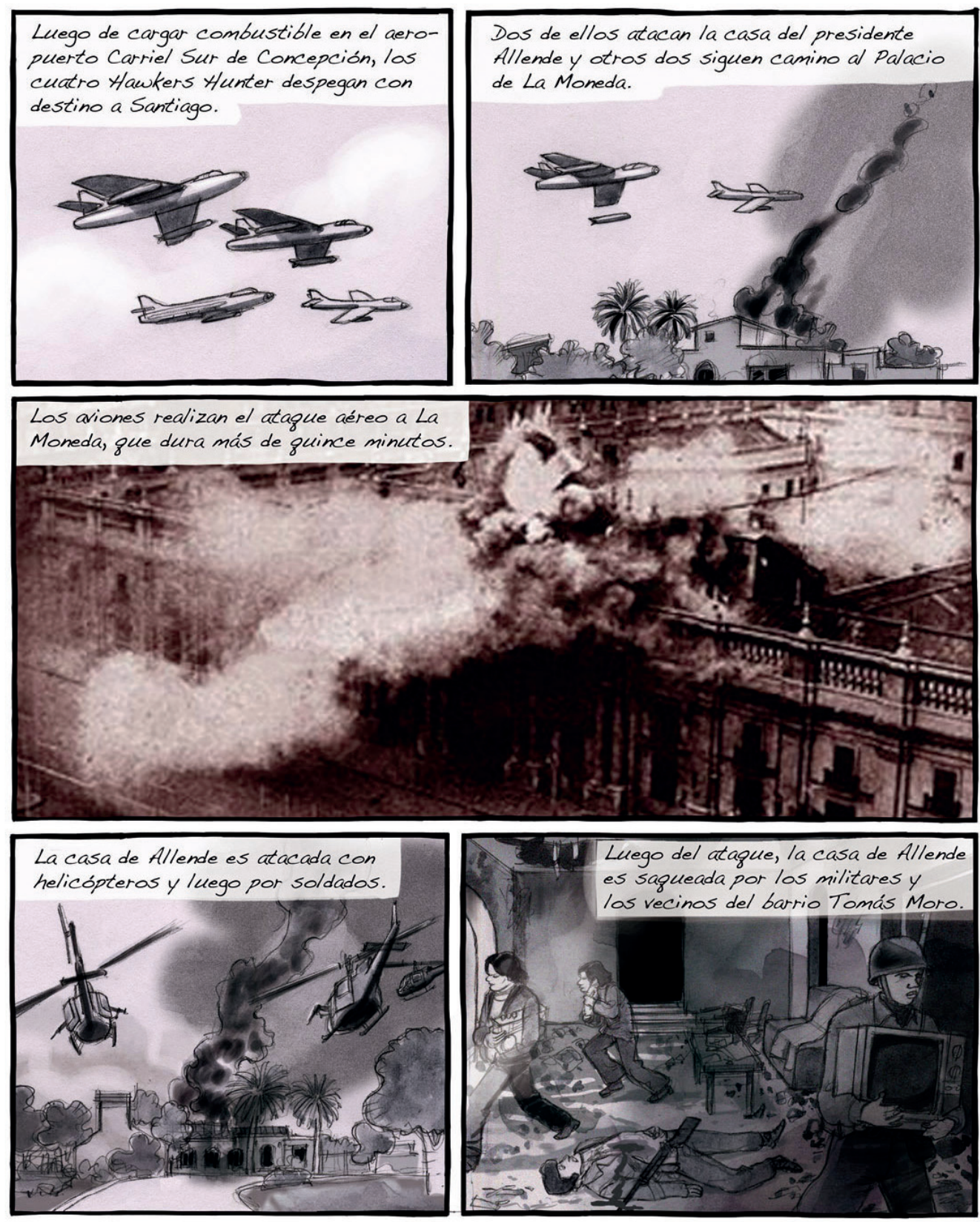

FIG. 4. Palomo, Q. y Cruz, N. Op. cit. Registro fotográfico da cuenta de la casa de gobierno bombardeada, mientras la vivienda del fallecido presidente de saqueada por fuerzas militares. 
Pero aquel momento de ideal social pronto se verá cruzado por la polarización que comenzará a sufrir el país. Grupos radicales como Patria y Libertad se mostrarán en acción, e incidentes como las elecciones parlamentarias de 1973 serán el escenario ideal para la efervescencia política. Mientras el relato avanza, crece la tensión social. Las colas, el desabastecimiento y la retención de productos, junto a los distintos paros irán mermando el progreso del gobierno y, paralelamente, podremos seguir las acciones de Julio y sus vecinos, quienes no solamente son espectadores de los hechos, sino también actores en el desarrollo del devenir social y político del país.

Las últimas páginas de esta novela gráfica, volcarán su atención en los textos, destacando las palabras finales del presidente Allende mientras estaba siendo víctima del golpe de estado. La tensión aumenta en la narración, intercalando fotografías del bombardeo a La Moneda, e imágenes del saqueo a la casa del primer mandatario (FIG. 4). Luego de esto el miedo y la represión, el ocultar las pruebas de cualquier vinculación con el gobierno y los primeros días de la Junta militar.

En paralelo, la madre del protagonista será obligada a permanecer en el hospital para atender la gran cantidad de heridos producto de las acciones de los militares en las primeras semanas post-golpe. Esta situación se verá agravada cuando la mujer entre en un colapso nervioso producto del horror del cual ella es testigo, al ver a jóvenes como sus hijos destrozados por las balas, y que la lleva a comprender que es la sociedad la que se destruye, un lugar que ya no será. La última escena de la obra será altamente simbólica. Una imagen del «Chamaco» Valdés metiendo un gol en aquel mítico encuentro contra la URSS, que lleva a Chile a clasificar al mundial sin jugar el partido.

Es interesante ver que a pesar de las citas explícitas a la historia, del afán de mostrar objetivamente el período, a través de imágenes ilustradas y algunas fotografías, los autores tomen partido y que finalmente propongan la obra no solo como el auge y caída de un gobierno, sino el de la construcción de un sueño que finalmente será truncado, y el cual siempre querremos soñar nuevamente.

\section{Los años de Allende. Con los ojos de un extraño}

Escrita por Carlos Reyes e ilustrada por Rodrigo Elgueta, esta novela gráfica publicada el año 2015 ha decidido abordar el mismo proceso, pero desde un punto de vista algo diferente, es decir, desde afuera (FIG. 5).

John Nitsch, corresponsal norteamericano, recibe el encargo de cubrir en el país las elecciones presidenciales de 1970, que conducirán al triunfo de la Unidad Popular. Bajo su atenta mirada periodística, el relato adquiere la forma de una crónica de los hechos, pormenorizando todos los incidentes que desembocarán en el golpe de estado de 1973. Es relevante señalar acá que la intención del relato es no tomar partido por alguno de los bandos que se confrontaron ideológicamente durante aquel periodo. 


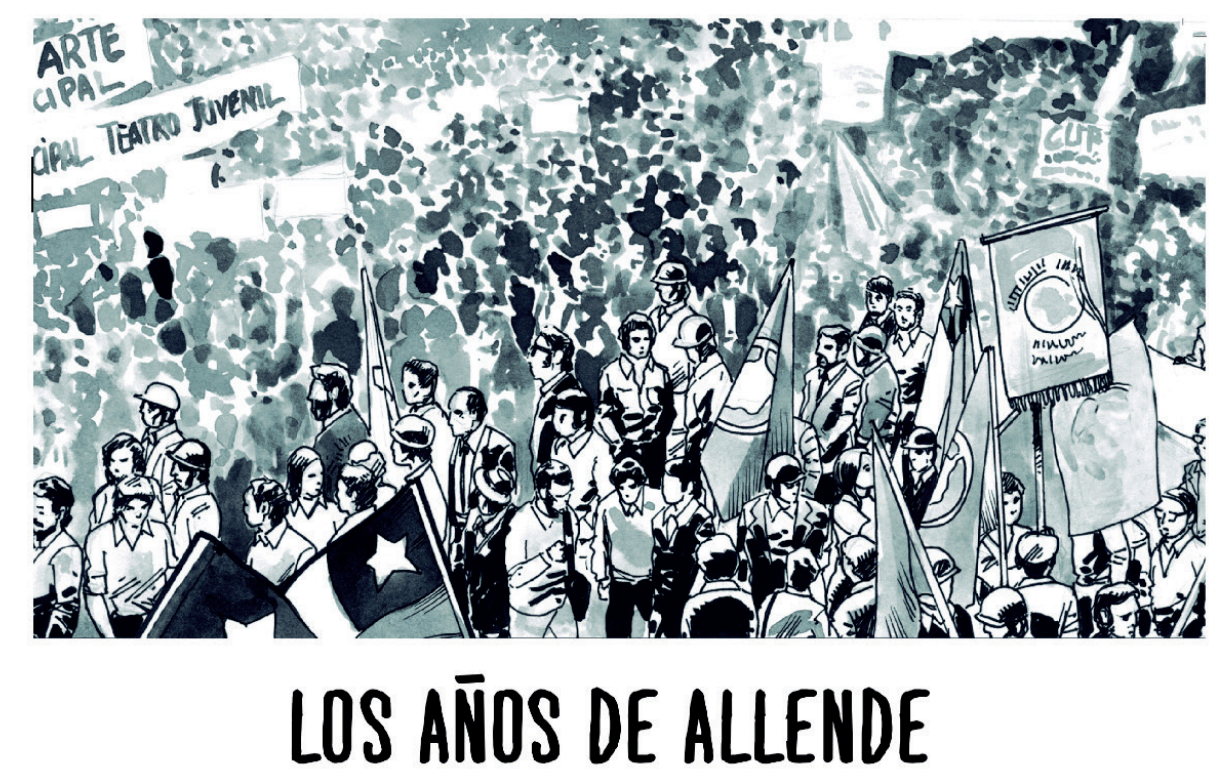

NOVELA GRÁFICA
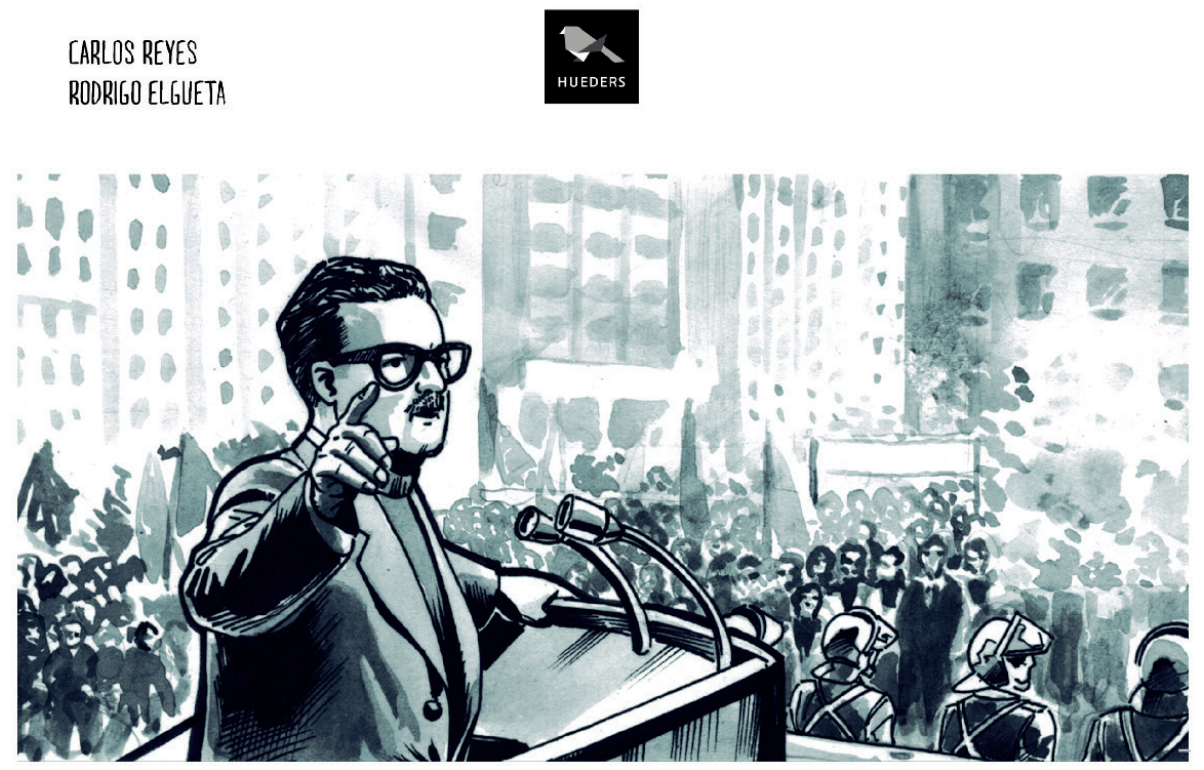

FIG. 5. Reyes, C. y Elgueta, R. Los años de Allende. Santiago, Editorial Hueders, 2015.

La estrategia utilizada para este fin fue la de darle voces y rostros a cada uno de los actores (FIG. 6) y bajo un acucioso trabajo de investigación ir integrando los diferentes incidentes y acciones. Son pocas las instancias en la narración en que se da pie para digresiones o aspectos subjetivos por parte del protagonista, quien siempre intenta mantener una posición neutral, aunque finalmente no sea del todo posible al involucrarse con Claudia y José, amigos chilenos que ven la vía armada como la única posibilidad para la revolución en Chile, y así lograr instaurar un régimen socialista en que el pueblo sea el protagonista. 

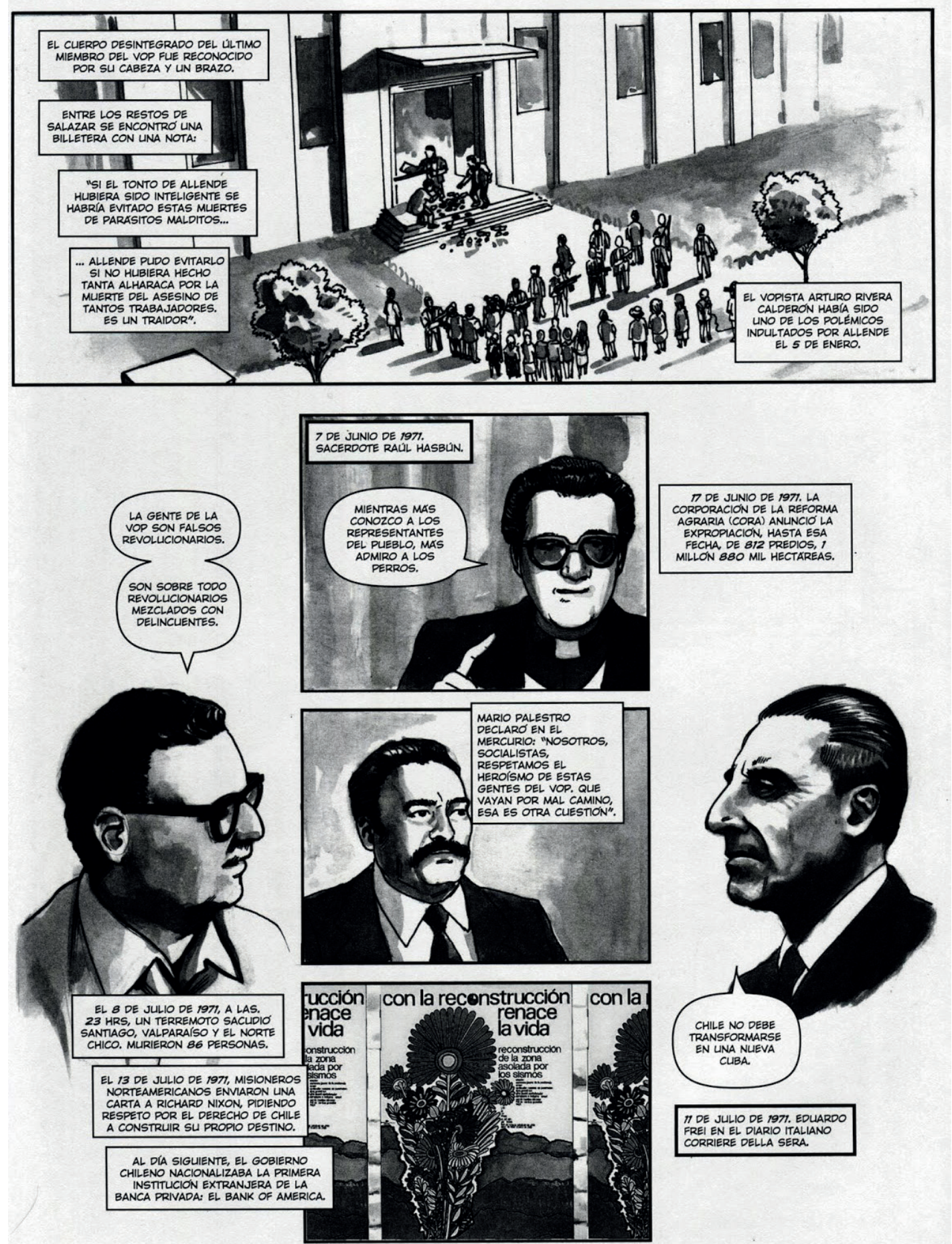

$61 \mid x$

FIG. 6. Reyes, C. y Elgueta, R. Op. cit. Los diversos sectores politicos representados. Ex presidentes, sacerdotes de derecha, parlamentarios, etcétera. 
La obra se manifestará como un gran relato coral, en donde la sensación final fue que todos los involucrados tuvieron algún grado de responsabilidad en las acciones que conducirían al quiebre del sistema democrático. Mientras la narración de $E l$ Golpe recurre a los mismos usos documentales para generar una lectura más menos objetiva de los hechos (con la dificultad de representación que ello implica), es el recurso de la crónica el que logra mejores resultados en mostrar un friso de acontecimientos que construyan un macro de alcances épicos. Curiosamente, esta gran cantidad de voces emitiendo sus discursos particulares, dará la sensación general de un diálogo de sordos, en donde pareciera que todos quisieran tener la razón. Para este propósito, es vital el trabajo de ilustración de Rodrigo Elgueta, quien logra darle rostro y vida a personajes que ya se han olvidado frente a las figuras omnipresentes de Pinochet y Allende. Carlos Prats, Mario Palestro, Miguel Enríquez, Carlos Altamirano, Orlando Saenz, Sergio Onofre Jarpa, y tantos otros son las voces de nuestra historia, quienes acá no solo sirven de referente histórico, sino que son parte del complejo entramado narrativo que es el proceso de la UP y el posterior golpe de estado. Para este propósito, el apartado gráfico esta vez no recurrirá al testimonio visual fotográfico para articular su reconstrucción del período, pero si deberá recurrir a referentes clásicos para generar una sensación de fidelidad histórica a los hechos (FIG. 7).

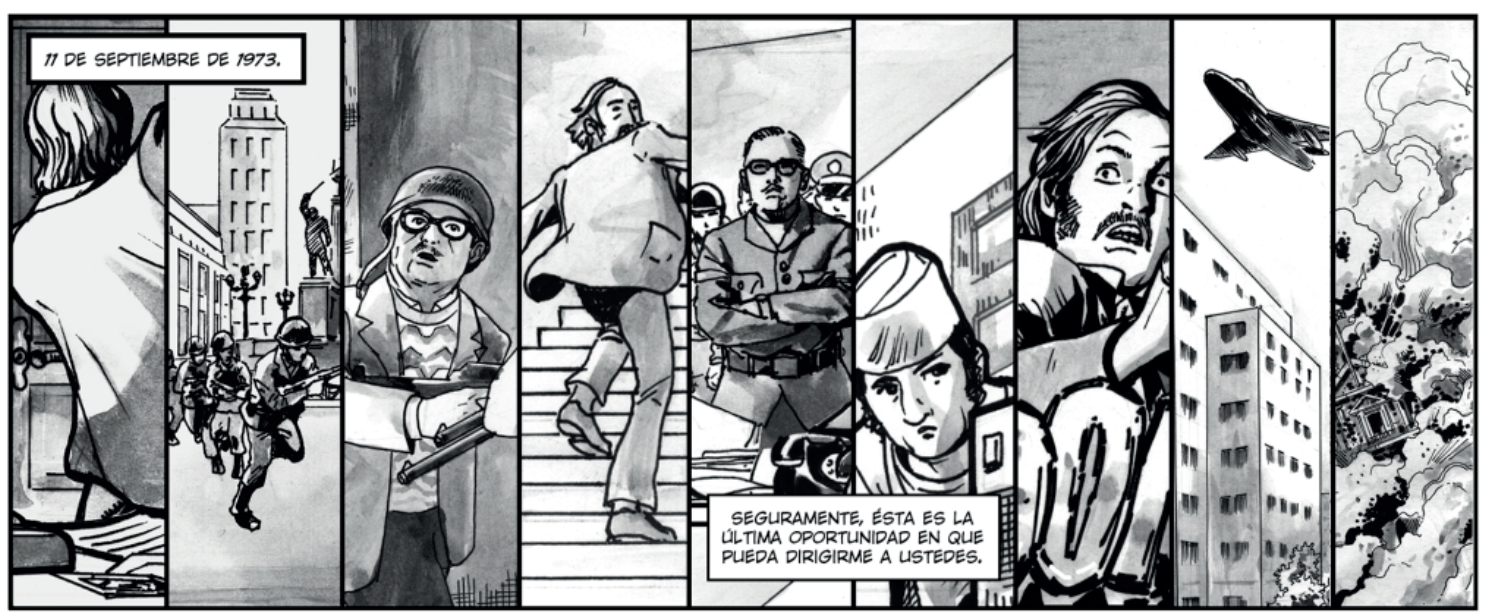

FIG. 7. Reyes, C. y Elgueta, R. Op. cit. Nuevamente el golpe como momento emblemático. Aquí vemos una composición con el presidente Allende preparado para el ataque, la junta representada por Pinochet, el periodista extranjero, $y$ algunas escenas del bombardeo.

Ahora, si bien el aspecto investigativo del período es sobresaliente (intentando no dejar ningún cabo fuera), esta necesidad de generar una lectura externa, a través de la figura del corresponsal extranjero, obligará a restarle peso a la ficcionalización, estableciendo la figura del periodista como la excusa para poder observar los hechos desde una supuesta neutralidad, la cual nunca es posible, menos aún en condiciones como las que se daban en aquel momento. Ese mismo aspecto de observador privilegiado, obligará a que el accionar personal pase a segundo plano y que sea la historia, aquella con mayúsculas, la verdadera protagonista del relato. 
Como comentario final, pero que me parece interesante consignar, la obra se da el gusto de hacerle un guiño a la propia tradición historietística (y editorial) nacional, cuando el personaje de John conoce las dependencias de la editorial Quimantú. Publicaciones como El intocable/el guerrillero, Cabro Chico, La Chiva, La firme, entre otras, además de algunos autores como Hervi, serán mostrados al lector en un gesto autoconsciente que afirma que, al igual que la memoria, la historieta está más viva que nunca (FIG. 8).

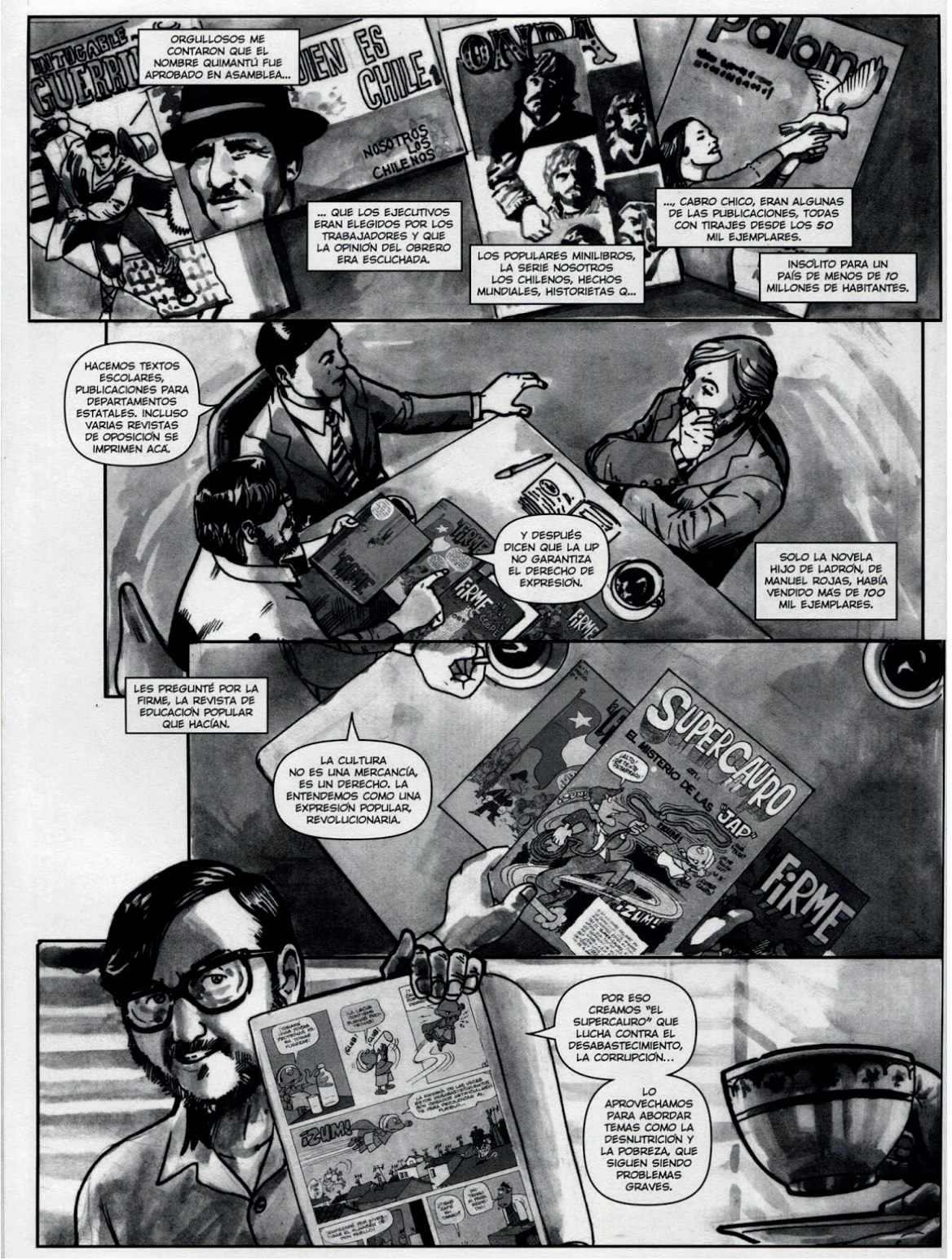

FIG. 8. Reyes, C. y Elgueta, R. Op. cit. Un homenaje a las publicaciones de la editorial estatal Quimantú, desmantelada luego del golpe de Estado. Se aprecian historietas como Intocable. El guerrillero, la revista de humor político La firme, entre otras. 


\section{Historias clandestinas. La memoria privada}

Para terminar este artículo, me gustaría referirme brevemente a esta obra publicada el año 2014, escrita por Sol Rojas Lizana e ilustrada por su hermano, Ariel Rojas Lizana. A diferencia de los ejemplos anteriores, nos encontramos con un relato que no solamente toma como referencia directa a los hechos históricos que condujeron al golpe de estado, sino que además añade la narración autobiográfica de lo que estos autores vivieron en su niñez, siendo actores y testigos presenciales de una sociedad en dictadura.

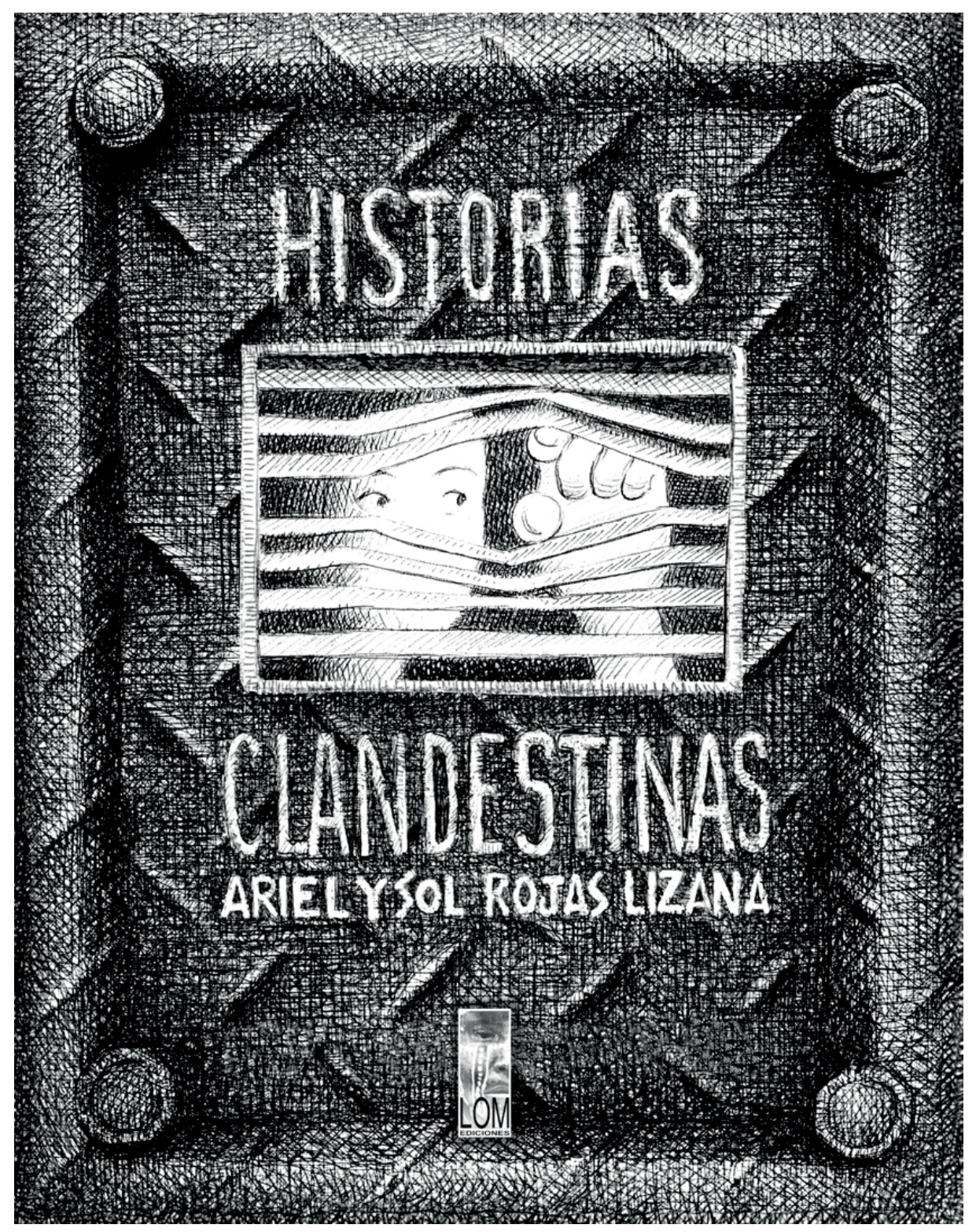

FIG. 9. Rojas Lizana, A. y Rojas Lizana, S.

Historias clandestinas. Santiago, Lom Ediciones, 2014. 
Luego del fatídico 11 de septiembre, pareciera que la realidad (y el país) es arrasada, y todo aquello que existía se vuelve un recuerdo, un sueño roto; pero la historia de Chile no es solo las grandes crónicas de los libros, sino también los relatos familiares que cruzan el camino de un país. Me parece relevante que pongamos también un ojo en aquellas historias mínimas que dan forma y sentido a un proceso que todavía no logra cerrarse. Como señala Peter Winn, «el "silencio" y el "olvido" ya no son maneras viables de abordar esa historia. Los historiadores saben desde hace tiempo que las construcciones del pasado tienen un contenido político tan controvertido como actual». ${ }^{32}$

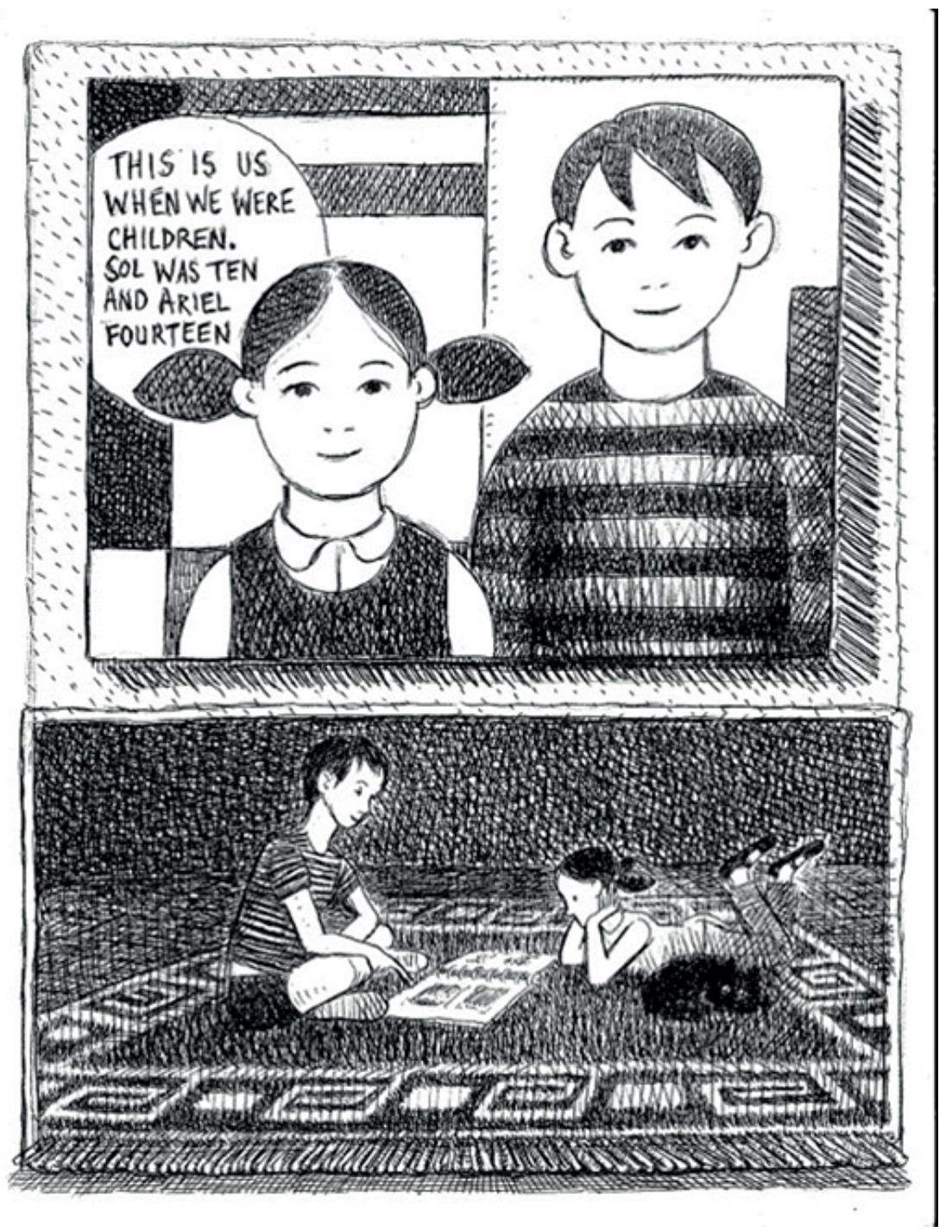

FIG. 10. Rojas Lizana, A. y Rojas Lizana, S.Op. cit. Parte de la edición inglesa, donde vemos a los hermanos en su infancia, etapa desde la cual narrarán los hechos.

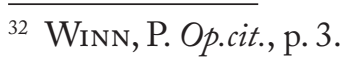


Esta generación que en aquel periodo estaba en su niñez también tiene una perspectiva de los hechos, y no podemos considerarlos meros observadores de los acontecimientos mientras los otros, los adultos, libran sus batallas y construyen la sociedad. Esa mirada al pasado debe situarse precisamente desde el lugar en donde nos ubicamos en aquel momento, y en este caso es uno bien reconocible. Menores de edad, con diez y catorce años, estos hermanos construyen esta novela gráfica como una manera de manifestar las voces de los que no hablaron en ese momento. Este relato autobiográfico, aun cuando pueda considerarse subjetivo, sigue teniendo un nivel de veracidad frente a lo acontecido, y se muestra de esa forma en su papel de consignar una memoria que vivió y sintió los hechos. Estas voces tomarán partido, porque acá la idea no es comprender las razones del trauma, sino situarnos en el espacio de lo íntimo (FIG. 10).

La narración comienza con un breve prólogo sobre la Unidad Popular y su ascenso al poder, que propondrá una lectura idealizada de aquel proyecto político, y lo situará en un estado utópico de bienestar. Este sueño de país luego será arrasado por el golpe de estado, y las imágenes (que aquí cobran mayor preponderancia) tienden a escenificar la zona del desastre. Con ello sobrevendrá la represión y la persecución política, los cambios radicales en la forma de ver y vivenciar la realidad. La escuela será un espacio restringido y las calles se volverán inseguras. Es el miedo el que se traspasa a lo cotidiano (FIG. 11).

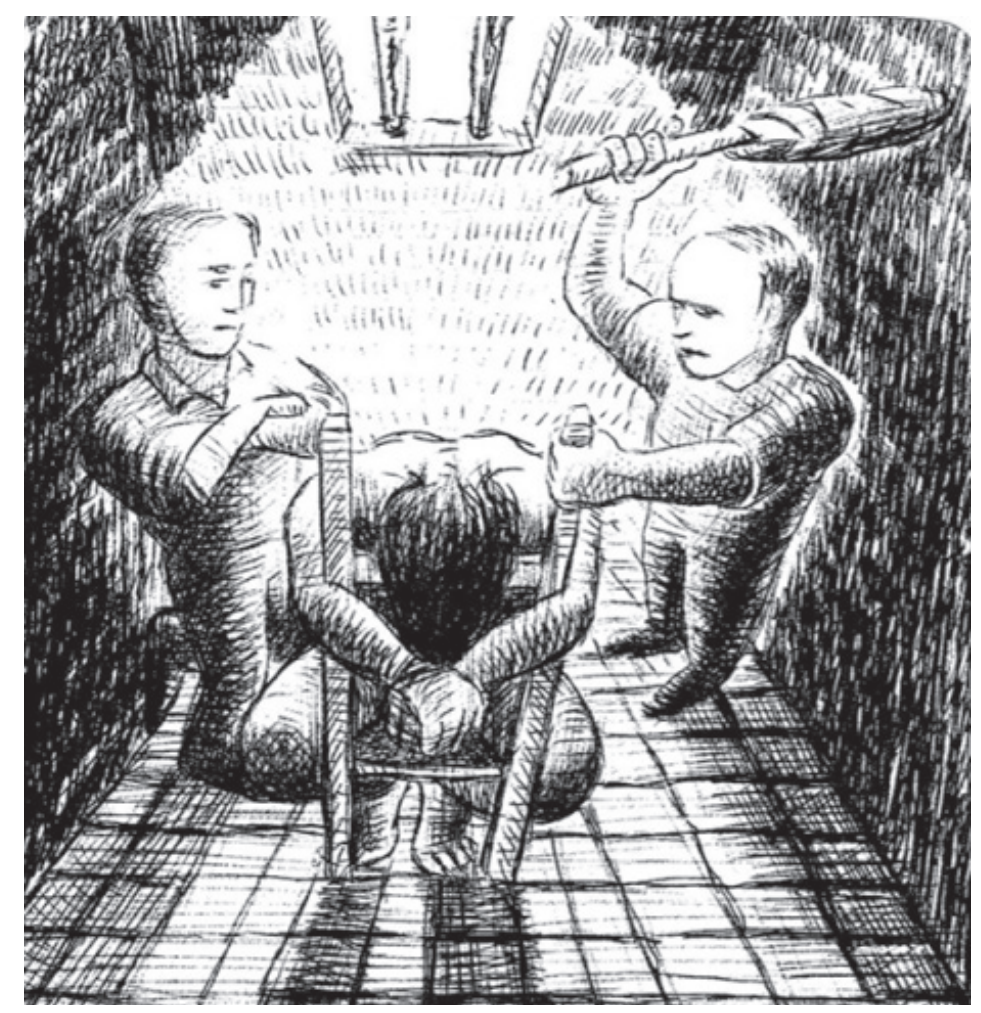

FIG. 11. Rojas Lizana, A. y Rojas Lizana, S. Op. cit. Uno de los aspectos más brutales de la dictadura fue la tortura a los detenidos políticos. 
También sabremos de Verónica y Ernesto, joven pareja que pretendía alojar una semana en casa de los niños, pero se queda diez años, producto del convulsionado momento que se vivía: Ernesto era el líder del MIR, luego de la muerte de Miguel Enríquez. Finalmente, la llegada de esta pareja alterará las relaciones internas familiares y llevará a que el padre deje la familia, al no aprobar la acción de ocultamiento.

Con el padre fuera de escena, los quehaceres cotidianos se alteran, abocándose a la lucha interna por la recuperación de la democracia. «El Rebelde», panfleto político, será armado durante los días en que esta pareja se oculta en la casa. Al igual que en Maus de Spiegelman, los autores nos mostrarán gráficamente los métodos que se utilizaron para ocultarse de las fuerzas militares y de gobierno, añadiendo un matiz de documento histórico sobre las acciones individuales realizadas para sobrevivir en este nuevo statu quo.

La vida se imbrica con el acontecer histórico. La televisión y la escuela transmiten los ideales del nuevo régimen, mientras en la clandestinidad se construyen himnos a la resistencia, se cavan subterráneos y se traslada a los líderes ocultos. La sociedad sigue avanzando y los cambios se profundizan, pero este relato pretende mostrarnos que los hechos mínimos, las historias individuales también generan grandes relatos. Es así que todo aquel accionar en las sombras con el correr de los años irá aflorando con mayor fuerza; las protestas y marchas, las manifestaciones de los familiares de detenidos desaparecidos y, finalmente, el retorno a la democracia serán el corolario de estos relatos clandestinos, pero la historia no se detiene (FIG. 12).

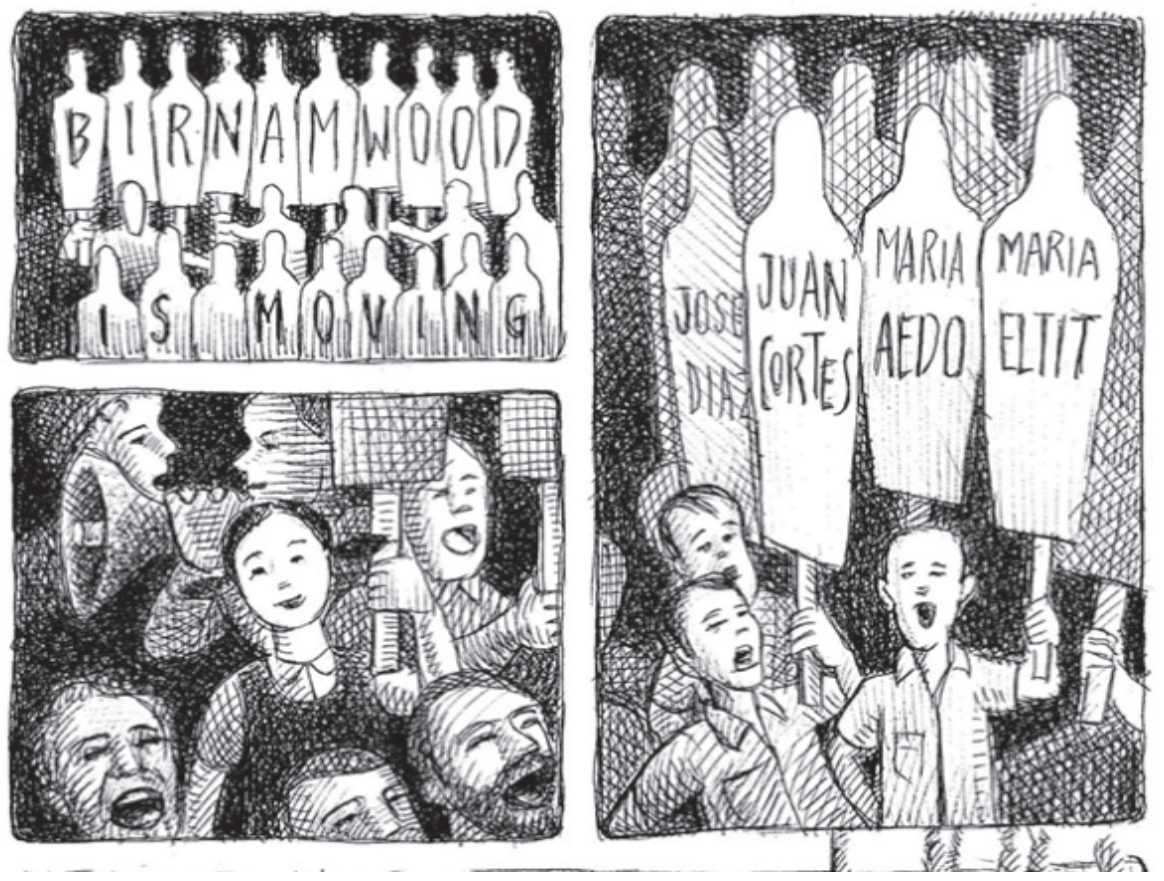

FIG. 12. Rojas Lizana, A. y Rojas Lizana, S. Op. cit. Las agrupaciones de familiares de detenidos desaparecidos todavía actúan en busca de verdad y justicia. 
Para los autores, las huellas de la dictadura siguen presentes en el modelo económico y social que hemos heredado de aquel periodo, en las desigualdades que observamos a diario y que han conducido a una sociedad individualista y con miedo. El desafío que propone la obra es mirar al pasado, ver los sueños e ideales que se han roto, para cuestionar lo que somos ahora, para reconstruirnos. Como indica Peter Winn «[e]1 pasado puede estar presente, pero el estudio de su memoria colectiva corresponderá al futuro». ${ }^{33}$

33 Ibid., p. 32. 


\section{Bibliografía}

Chartier, R. A História Cultural: entre práticas e representaóes. Río de Janeiro, Editora Bertrand, Brasil, 1990.

Didi - Huberman, G. «Repartos de comunidades», en Pueblos expuestos, pueblos figurantes. Buenos Aires, Manantial, 2014, pp. 95-146.

EFE. «Los motivos tras el reciente boom de novelas gráficas centradas en la historia de Chile», en Emol, 18 de junio de 2015. Disponible en http://www.emol.com/noticias/ Cultura-y-Espectaculos/2015/06/18/722102/Pinochet-y-Allende-en-los-comics.html

Gaborit, M. «Memoria histórica: relato desde las víctimas», en Pensamiento Psicológico, vol. 2, n. ${ }^{\circ} 6$ (2006), pp. 7-20.

García Canclini, N. Culturas hibridas. Estrategias para entrar y salir de la modernidad. México, Editorial Grijalbo, 1990, p. 263.

Hall, S. «El trabajo de la representación», en Representation: Cultural Representations and Signifying Practices. London, Sage Publications, 1997, pp. 13-74. Traducido por Elías Sevilla Casas.

Huyssen, A. «El Holocausto como historieta. Una lectura de Maus de Spiegelman», en En busca del futuro perdido cultura, memoria en tiempos de globalización. México, FCE, 2001, pp. 119-141.

Mariniello, S. Cambiar la tabla de operación. El medium intermedial. México, Revista Acta Poética 30-2, otoño 2009.

Palomo, Q.y Cruz, N. El golpe. El pueblo 1970-1973. Santiago, Pehuén Editores, 2014.

Reyes, C. y Elgueta, R. Los años de Allende. Santiago, Editorial Hueders, 2015.

Rojas Lizana, A. y Rojas Lizana, S. Historias clandestinas. Santiago, Lom Ediciones, 2014.

Trabado, J. M. «La novela gráfica en el laberinto de los formatos del cómic», en La novela gráfica. Poéticas y modelos narrativos. Madrid, Editorial Arco/Libros, 2013, p.11-61.

White, H. El contenido de la forma. Narrativa, discurso y representación histórica. Barcelona, Paidós, 1992.

—El texto histórico como artefacto literario. Barcelona, Paidós, 2003. 
WILDE, A. «Irrupciones de la memoria: la política expresiva en la transición a la democracia en Chile», en Historizar el pasado vivo, Universidad Alberto Hurtado, 2007. Disponible en http://www.historizarelpasadovivo.cl/downloads/wilde.pdf

Winn, P. «El pasado está presente. Historia y memoria en el Chile contemporáneo», en Historizar el pasado vivo, Universidad Alberto Hurtado, 2007. Disponible en http:// www.historizarelpasadovivo.cl/downloads/winn.pdf 